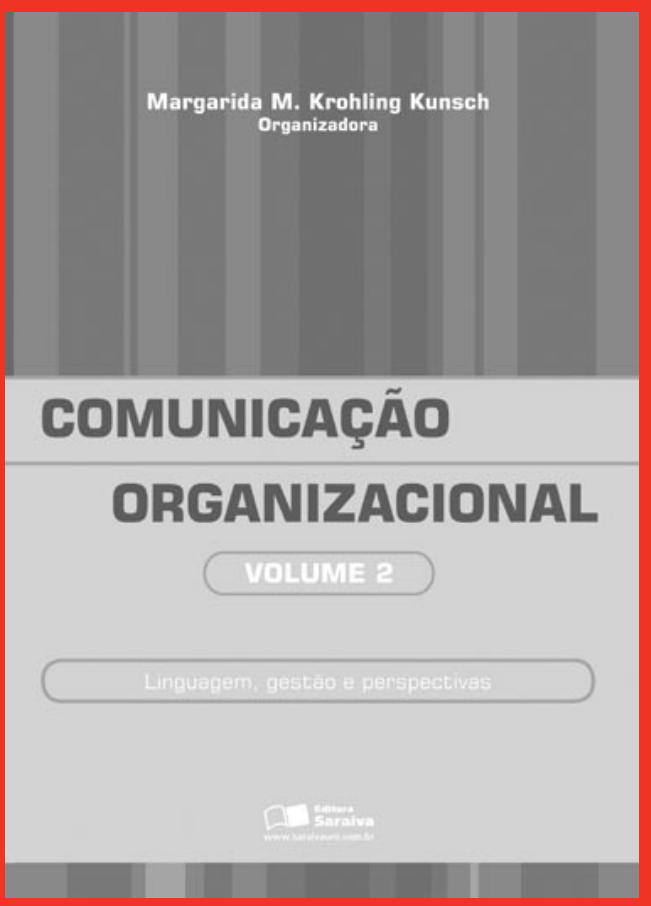

Comunicação organizacional. Vol. 2. Linguagem, gestão e perspectivas

Margarida M. Krohling Kunsch (Org.)

São Paulo, SP

Saraiva, 2009

360 páginas

Resenhado por:

Ricardo Caribé

- Mestre e doutorando em Administração pela Universidade Federal da Bahia (UFBA)

- Especialista em Gestão Empresarial e graduado em Relações Públicas

- Coordenador do curso de Especialização em Gestão da Comunicação Organizacional Integrada da UFBA

- Diretor da Tábuas da Ponte Comunicação Organizacional

- Sócio-fundador da Associação Brasileira de Pesquisadores de Comunicação

Organizacional e de Relações Públicas (Abrapcorp)

- Atua na área de comunicação organizacional desde 1991

- ricardo@tabuasdaponte.com.br 


\title{
Da instrumentalidade ao processo social da Comunicação Organizacional
}

\author{
From instrumentality to the social process \\ of Organizational Communication
}

\section{De la instrumentalidad al proceso social de la Comunicación Organizacional}

\begin{abstract}
segundo volume, Linguagem, gestão e perspectivas, da coletânea Comunicação organizacional, publicada pela pesquisadora Margarida M. Krohling Kunsch, reúne quatorze trabalhos representativos da produção intelectual brasileira na área de Comunicação Organizacional nos últimos anos. Em sua primeira parte, batizada de "Retórica e discursos organizacionais", demonstra-se a força da pesquisa fundamentada nas Ciências da Linguagem. Na segunda, "Gestão da comunicação e das mudanças culturais", evidencia-se a forte integração multidisciplinar que a área experimenta com a Antropologia, a Sociologia, a Psicologia, a Política e a Administração.
\end{abstract}

Dentre os oito artigos de alto nível que compõem a primeira parte, três se destacam ao privilegiar a abordagem da Comunicação Organizacional como campo de estudo. Com "Identidade organizacional e a construção dos discursos organizacionais", Luis Carlos Iasbeck abre a obra em grande estilo, tratando da identidade das organizações, de seus múltiplos discursos e da constituição de sua imagem. Ele advoga a tese da interdependência dessas categorias e defende que a identidade, se em alguma medida gerenciável, o é pela possibilidade de se atuar na elaboração dos discursos e, simultânea e correspondentemente, nos processos de percepção simbólica e recepção desses discursos pelos públicos. Complementarmente, em "Discurso organizacional: uma abordagem retórica”, Tereza Lúcia Halliday enfatiza o lugar do discurso organizacional como ação e como recurso estratégico das organizações que se empenham na construção simbólica da realidade. Ela premia o leitor com uma introdução à técnica da análise retórica e resgata a reflexão sobre a Comunicação Organizacional como retórica da legitimação. No terceiro texto, "A contribuição das ciências da linguagem para o estudo da comunicação organizacional", as pesquisadoras Anely Ribeiro e Elena Godói lançam mão da Linguística Aplicada como método para investigar questões centrais da Comunicação Organizacional, como a consideração dos públicos no processo de construção simbó- 
lica da realidade. Elas apresentam o conceito de competência comunicativa e constatam que é preciso ampliar a integração multidisciplinar dos estudos teóricos da área, os quais devem valer-se sobretudo dos aportes da Linguística, dos Estudos Culturais e da Psicologia Social.

Os demais artigos da primeira parte, por sua vez, apontam para as significativas e particulares contribuições que as Ciências da Linguagem trazem para a Comunicação Organizacional. Alvair Torres Júnior, em "Comunicação organizacional: retórica e dramaturgia na implantação de um novo modelo de produção", propõe uma nova vertente investigativa para a área - a retórica dramatúrgica. Outra contribuição metodológica à Comunicação Organizacional é dada por Cleonice de Mendonça Van Raij, que demonstra de modo interessante o emprego da análise do discurso como método em seu texto "Análise de um discurso organizacional".

Em um ensaio instigante, Maria José de Figueiredo Garcia utiliza a Semiótica discursiva para refletir sobre a formação de gestores em comunicação e cultura organizacional, a partir da apreciação de sua produção científica na área entre 2003 e 2005. No artigo "A formação dos gestores em cultura e comunicação organizacional: o ponto de vista da semiótica discursiva", a autora realça os caminhos de significação e de subjetividade trilhados pelos gestores nas suas experiências de pesquisa científica.

A partir de três categorias de enunciados próprios do universo organizacional, em "Organizações: um universo de discursos bem-ditos, mal-ditos e nãoditos", Artur Roberto Roman discorre sobre a administração da Comunicação Organizacional, cujo desafio central seria a convivência "com essa polifonia de discursos que se entrecruzam caleidoscopicamente nas redes interacionais do universo corporativo" (p. 155). E, encerrando a primeira parte, Jair de Oliveira, em " $(\mathrm{Re})$ vendo a linguagem: uma análise crítica da comunicação organizacional", presenteia o leitor com uma observação cuidadosa das práticas linguísticas próprias do universo intraorganizacional, por meio de um ensaio sobre modelos explicativos vigentes. Crítico, entende o ambiente organizacional como uma "arena axiológica" (p. 190) e se vale de uma teoria do uso da linguagem - uma pragmática - preocupada com os atores/produtores da linguagem e as relações/os processos de construção da linguagem e não com o produto: a linguagem em si.

Na segunda parte do livro, o leitor tem contato com experiências marcadas por influências multidisciplinares. Dois trabalhos sobressaem pela densidade e por favorecerem a melhor compreensão dos demais: "A cultura organizacional como manifestação da multidimensionalidade humana", de Maria Schuler, que se encarrega de demonstrar a interpenetração dos conceitos de comunicação, organização e cultura, apoiada por um outro conceito estruturante: o de representações sociais; e "Agenciamento comunicacional e mudança organizacional estratégica”, no qual Maria do Carmo Reis observa processos de mudança or- 
ganizacional significativa em três corporações internacionais e o papel reservado à comunicação nesses processos, sustentando a autora que a comunicação é elemento constitutivo da mudança e não simplesmente um dos seus instrumentos.

O olhar de quem vive o mundo concreto das organizações se revela nos textos de Ana Luisa de Castro Almeida, "Identidade, imagem e reputação organizacional: conceitos e dimensões da práxis", e de Graça Monteiro e Jorge Duarte, "Potencializando a comunicação nas organizações", ambos desveladores de intrigantes objetos a serem pesquisados. "As interconexões entre cultura organizacional e comunicação", de Marlene Marchiori, revela a vastidão do entrelaçamento conceitual possível entre essas categorias. Já Ivone de Oliveira, em seu não menos interessante artigo, "Espaços dialógicos e relacionais nas organizações e sua natureza ético-política”, demonstra sua inquietação pertinente com abordagens que subordinem o campo da Comunicação Organizacional e faz a defesa da aproximação entre esse campo e o da Política - ou com pelo menos algumas de suas subcategorias significativas.

Assim como o primeiro volume da coletânea Comunicação organizacional, esse segundo volume da coletânea de Margarida Kunsch é leitura recomendada a todos que se interessam pelo mapeamento do estado da arte do campo no Brasil, constituindo-se em mais uma das muitas e valiosas contribuições da organizadora à Comunicação Organizacional e às Relações Públicas. 